\title{
Gas/Liquid Membranes For Natural Gas Upgrading
}

Quarterly Report No. 7

Reporting Period Start Date: October 1, 2002

Reporting Period End Date: June 30, 2003

Principal Author: Howard S. Meyer, Principal Manager, Gas Processing Research GTI Project 61147

Issued: July 2003

Contract Number: DE-FC26-01NT41227

To

Anthony M. Zammerilli

Project Manager

National Energy Technology Laboratory

P.O. Box 880

3610 Collins Ferry Road

Morgantown, WV 26507

By

\author{
GAS TECHNOLOGY INSTITUTE \\ 1700 South Mount Prospect \\ Des Plaines, IL 60018-1804
}




\title{
Gas/Liquid Membranes For Natural Gas Upgrading
}

\author{
GTI Project 61147 Contract Number: DE-FC26-01NT41227
}

\section{DISCLAIMER}

This report was prepared as an account of work sponsored by an agency of the United States Government. Neither the United States Government nor any agency thereof, nor any of their employees, makes any warranty, express or implied, or assumes any legal liability or responsibility for the accuracy, completeness, or usefulness of any information, apparatus, product, or process disclosed, or represents that its use would not infringe privately owned rights. Reference herein to any specific commercial product, process, or service by trade name, trademark, manufacturer, or otherwise does not necessarily constitute or imply its endorsement, recommendation, or favoring by the United States Government or any agency thereof. The views and opinions of authors expressed herein do not necessarily state or reflect those of the United States Government or any agency thereof. 


\section{Gas/Liquid Membranes For Natural Gas Upgrading}

GTI Project 61147 Contract Number: DE-FC26-01NT41227

\section{ABSTRACT}

Efforts this quarter have concentrated on field site selection. ChevronTexaco has nominated their Headlee Gas Plant in Odessa, TX for a commercial-scale dehydration test. Design and cost estimation for this new site are underway. Potting and module materials testing continued. Preliminary design of the bench-scale equipment continues.

\section{TABLE OF CONTENTS}

DISCLAIMER

ABSTRACT

TABLE OF CONTENTS

INTRODUCTION

EXECUTIVE SUMMARY

EXPERIMENTAL

RESULTS AND DISCUSSION

CONCLUSION

REFERENCES

\section{INTRODUCTION}

Gas Technology Institute (GTI) is conducting this research program whose objective is to develop gas/liquid membranes for natural gas upgrading to assist DOE in achieving their goal of developing novel methods of upgrading low quality natural gas to meet pipeline specifications.

Kværner Process Systems (KPS) and W. L. Gore \& Associates (GORE) gas/liquid membrane contactors are based on expanded polytetrafluoroethylene (ePTFE)

membranes acting as the contacting barrier between the contaminated gas stream and the absorbing liquid. These resilient membranes provide much greater surface area for transfer than other tower internals, with packing densities five to ten times greater, resulting in equipment $50-70 \%$ smaller and lower weight for the same treating service.

The scope of the research program is to (1) build and install a laboratory- and a fieldscale gas/liquid membrane absorber; (2) operate the units with a low quality natural gas feed stream for sufficient time to verify the simulation model of the contactors and to project membrane life in this severe service; and (3) conducted an economic evaluation, based on the data, to quantify the impact of the technology. Chevron, one of the major producers of natural gas, has offered to host the test at a gas treating plant. KPS will use their position as a recognized leader in the construction of commercial amine plants for 


\title{
Gas/Liquid Membranes For Natural Gas Upgrading
}

\author{
GTI Project 61147 Contract Number: DE-FC26-01NT41227
}

building the unit along with GORE providing the membranes. GTI will provide operator and data collection support during lab- and field-testing to assure proper analytical procedures are used. Kværner and GTI will perform the final economic evaluation. GTI will provide project management and be responsible for reporting and interactions with DOE on this project.

\section{EXECUTIVE SUMMARY}

The cofunding agreement with ChevronTexaco continues under discussion.

ChevronTexaco's Chinchaga Gas Plant in Alberta, Canada will not be increasing capacity as planned. Since they do not have a commercial need for the contactor, they have withdrawn that site and are seeking another suitable location. We continue seeking alternative hosts and sites as a backup. A meeting was held with ChevronTexaco in Denver last quarter, 2002 to identify potential locations. Most of their needs are outside the North American market. They have asked for a test unit design for a West African site. Discussions have begun for a potential application at their Carter Creek Plant in Wyoming. This site handles a high-pressure natural gas stream with $16 \% \mathrm{H}_{2} \mathrm{~S}$ requiring treatment to bring it to $4 \mathrm{ppm}$.

Last quarter, ChevronTexaco identified a potential test site in West Texas. The application here is for a full-scale dehydration unit, similar in size as originally proposed, but for a different natural gas processing application. A meeting was held with ChevronTexaco, GTI and KPS at the Headlee Gas Plant in Odessa, TX, to investigate testing, contract terms, schedules, and responsibilities. Key issues and decisions are described below.

1. Membrane module design basis - The original plan was that the module skid would be designed for a new offshore Nigeria platform and would have a capacity of $100 \mathrm{MMscfd}$. Only one 50 MMSCFD membrane module would be installed on the skid for the field test. Since it cannot be determined at this time which of several offshore Nigeria platforms would be the final destination of the skid, it was decided to modify the design basis of the membrane module. The initial membrane module would be based on the largest diameter module that Kvaerner feels comfortable fabricating. Currently, this is about $72 \mathrm{~cm}$. The design conditions for the module (temperature, pressure, water content, TEG quality, water removal requirements) were provided to Kvaerner. The nominal capacity is $50 \mathrm{MMscfd}$ for the $72 \mathrm{~cm}$ diameter module at the design conditions.

2. The proposed skid connection plan was reviewed prior to a tour of the plant. After the tour, a few changes to the plan were suggested and adopted. a) It was decided to move the gas flow bypass valve off of the skid. This has the advantage of designing the valve and bypass line for a lower pressure. b) A booster pump may be required on the lean TEG stream.

3. The current average flow through the TEG contactor is about $65 \mathrm{MMscfd}$. Due to field production operating system, the flow may vary by plus or minus $15 \mathrm{MMscfd}$ over an hour period. 


\title{
Gas/Liquid Membranes For Natural Gas Upgrading
}

\author{
GTI Project 61147 Contract Number: DE-FC26-01NT41227
}

4. Cliff Lowe will serve as ChevronTexaco's contact point for technical issues, while Karl Gerdes will be the contact point for commercial issues, and Barry Sparkman is the plant engineer.

5. The critical path for the project is obtaining an agreement on the purchase contract.

6. PFD's, P\&ID's were supplied to Kvaerner.

7. A lean TEG sample was provided to GTI for analysis.

8. Kvaerner Norway will provide a draft of the project schedule.

\section{EXPERIMENTAL}

\section{ChevronTexaco module:}

The modified simulation program has been used for designing a 50 MMscfd membrane contactor module for industrial scale dehydration testing. ChevronTexaco wants to demonstrate the technology in Odessa, Texas for possible subsequent utilization at a new planned platform outside the west coast of Nigeria.

The design pressure and temperature is 83 barg (1200 psig) and $115 \mathrm{~F}$. The gas has to be dried from saturated ( $76 \mathrm{lbs} / \mathrm{MMscf}$ ) to $7 \mathrm{lbs} / \mathrm{MMscf}$. The Nigerian application will require a higher pressure and additional water removal. ChevronTexaco and KPS are negotiating commercial terms for a "try and buy" sales agreement for the test unit. They are planning a 180-day endurance test with 3 performance test periods throughout the endurance test. During the performance tests, gas and liquid flow rates, glycol purity (water content of the lean glycol), and temperatures will be varied to provide modeling data required to project performance of the Nigerian application.

The project is being re-scoped for this new site and application. ChevronTexaco will perform the site preparation and installation. KPS will design the membrane contactor and contactor skid. The key component, the membrane contactor, will be produced in cooperation with the membrane manufacturer, Gore, and the module manufacturer, SGL Carbon Group. The commissioning, start-up and tests will be performed in close cooperation with GTI, ChevronTexaco, and KPS. In addition to technical support, GTI will also be heavily involved in the sampling, evaluation of the data, and perform a third party evaluation of the results.

The first critical milestone for this site is the tie-ins to be performed during a major plant shut-down in mid-October, 2003. The Haz-Op analysis is planned for late August, 2003. Testing would begin during the second half of 2004.

\section{Potting project:}

The present potting material has its limitation in the casting of larger diameters due to high exothermic peak and subsequent cracking of cured material. Therefore, a search for a new thermosetting material was initiated.

\section{Resin survey:}




\section{Gas/Liquid Membranes For Natural Gas Upgrading}

GTI Project 61147 Contract Number: DE-FC26-01NT41227

Ten resin systems were chosen for initial screening. The following parameters were tested and evaluated:

- $\quad$ exothermic heat

- viscosity

- $\quad$ infiltration behavior (distribution around membranes and spacers)

- $\quad$ flexibility

- $\quad$ adhesion to the membrane (peeling tests)

The six most promising systems were chosen for the chemical immersion test to evaluate chemical resistance.

The resins include room temperature curing PU-systems (polyurethane), EP-systems (epoxy) and high temperature curing epoxy-system $\left(80^{\circ} \mathrm{C}\right)$ from four different suppliers.

\section{Chemical immersion test:}

The most common gas treatment absorbents were picked out for the test where resin samples (including membrane and spacer) are exposed for 24 weeks at $60^{\circ} \mathrm{C}$. The following solvents were chosen:

- TEG

- MEA

- MDEA

- aMDEA (highly activated from BASF)

- Morphysorb

- Selexol/Genosorb

As a measure for chemical resistance, the adhesion between membrane/PTFE and resin was chosen in addition to swelling of sample. Chemical resistance test will be performed after 6,12 , and 24 weeks. The test will be finished in beginning of June 2003.

Parallel to the chemical testing the following activities will be performed:

- potting simulations, i.e. study of the rheological behavior of approx. $3 \mathrm{~kg}$ samples of the various resins in a plexiglass mould of length/diameter $720 \mathrm{~mm}$ which is filled with membrane sheets and spacer material

- building dummies of the full size diameter and thickness (approx. $40 \mathrm{~kg}$ resin), both to see the rheological behavior and the curing performance in full scale

- the new potting material will be ready in July 2003

\section{RESULTS AND DISCUSSION}

\section{Chemical immersion test:}




\section{Gas/Liquid Membranes For Natural Gas Upgrading}

GTI Project 61147 Contract Number: DE-FC26-01NT41227

The chemical-immersion potting tests have been running for approximately 16 weeks. The table below shows the test results after 13 weeks for the most promising samples.

\begin{tabular}{|c|c|c|c|c|c|c|}
\hline & \multicolumn{2}{|c|}{ TEG } & \multicolumn{2}{c|}{ aMDEA } & \multicolumn{2}{c|}{ Morphysorb } \\
\hline & Swelling (\%) & Consistency & Swelling (\%) & Consistency & Swelling (\%) & Consistency \\
\hline Epoxy 1 & 9.05 & 2 & 4.12 & 3 & 25.48 & 1 \\
\hline Epoxy 2 & 7.49 & 4 & 1.26 & 4 & 24.97 & 1 \\
\hline Epoxy 3 & 3.85 & 4 & 1.42 & 4 & 15.09 & 2 \\
\hline
\end{tabular}

The swelling is measured as an increase in sample thickness while the consistency is a qualitative measure where 4 is as hard as the initial potting and 1 is soft. Epoxy 1 is the original potting material used and is the reference material here. Epoxy 3 causing machining problems because of its extreme hardness. Epoxy 2 appears promising as a usable material. Compared to the reference material, Epoxy 2 has less swelling for both TEG and aMDEA.

Currently, only Epoxy 2 can be used for the ChevronTexaco module. To increase design flexibility, additional resin systems are being collected. Five new promising epoxy systems are ready for chemical testing.

The proper potting materials for physical solvents continue to be sought. Neither polyurethane nor epoxy systems seem to have sufficient chemical resistance. Initial testing with a new resin has shown good viscosity and peak exothermal behavior, but poor adhesion to the membrane sheet. SGL and Gore will cooperate to identify an appropriate system.

\section{Potting simulation test:}

Potting simulation tests were performed with the Epoxy 2 system. The liquid resin is injected from the bottom of the mould up to a predefined level. The tests show that the epoxy liquid is leveling out smoothly before the gel point is reached.

\section{Hazardous Substance Plan:}

The Hazardous Substance Plan for this project was submitted this quarter. It identified $\mathrm{H}_{2} \mathrm{~S}$ (U135) as the only hazardous substance for this project. Lab use is expected to be nominally 1.5 pounds in mixed gas supplied cylinders.

\section{CONCLUSION}

No conclusions have been reached at this point.

\section{REFERENCES}

None 